\title{
Efficacy of Metarhizium anisopliae, Beauveria bassiana and neem oil against tomato fruit borer, Helicoverpa armigera under field condition
}

\author{
M. PHUKON ${ }^{1}$, I. SARMA ${ }^{1}$, R. BORGOHAIN ${ }^{1}$, B. SARMA ${ }^{2}$ AND J. GOSWAMI ${ }^{3}$ \\ ${ }^{1}$ Krishi Vigyan Kendra (A.A.U.), Kaliapani, CHANGMAIGAON (ASSAM) INDIA \\ Email : mousumiphukon@yahoo.in \\ ${ }^{2}$ Krishi Vigyan Kendra (A.A.U.), Kajalgaon, CHIRANG (ASSAM) INDIA \\ ${ }^{3}$ Directorate of Extension Education, Assam Agricultural University, JORHAT (ASSAM) INDIA
}

\begin{abstract}
A field study was conducted at farmers field of Jorhat, Assam during 2010-11 to evaluate the efficacy of three commercial biopesticides, two based on insect pathogenic fungi viz., Beauveria bassiana and Metarhizium anisopliae and one botanical-Neem oil in comparison with chemical-cypermethrin against the tomato fruit borer (Helicoverpa armigera). The study revealed the reduction in fruit damage was upto 92.20 per cent in cypermethrin treated plot followed by 91.12 per cent, 88.74 per cent and 87.01 per cent in the plots treated with Neem oil, B. Bassiana and M. Anisopliae, respectively due to H. armigera larvae over control. The study showed that neem oil was nearly as effective as cypermethrin in reducing fruit damage leading to increased yield. The highest increase in yield over control was noticed in cypermethrin treated plots $(62.85 \%)$ followed by neem oil treated plots $(41.83 \%)$.The entomopathogenic fungi- Beauveria bassiana and Metarhizium anisopliae could be effectively used as pest management option in production of organic tomato to reduce the pest population below economic threshold level and increased yield.
\end{abstract}

Key words : Metarhizium anisopliae, Beauveria bassiana, Neem oil, Helicoverpa armigera

How to cite this paper : Phukon, M., Sarma, I., Borgohain, R., Sarma, B. and Goswami, J. (2014). Efficacy of Metarhizium anisopliae, Beauveria bassiana and Neem oil against tomato fruit borer, Helicoverpa armigera under field condition. Asian J. Bio. Sci., 9 (2) : 151-155. 